\title{
Barriers to Parental Involvement in Early Childhood Education Classrooms in Mumbai Slums as Perceived by Parents
}

\author{
Asha Menon \\ Dept of Human Development, S.P.N. Doshi Women's College, Cama Lane, Ghatkopar (W), \\ Mumbai-400086, India
}

\begin{abstract}
Involving parents in school activities is a tradition based on theory and research. The present study aims to find the barriers to parental involvement in early childhood education classrooms in the Mumbai slums as perceived by parents. A sample of 150 parents was selected from 10 preschools schools in the slums of Mumbai. Purposive sampling technique and a self constructed rating scale was used. The results showed that 32\% of fathers were in the age group of 31-35 years where as $38.6 \%$ of mothers were in the age group of 26-30 years. It is seen that 41 fathers were primary school pass and only 6 parents had passed secondary school. Majority of the mothers were illiterates (38) and only 2 mothers had passed secondary school. Majority of the fathers (23) were auto rickshaw drivers where as 55 mothers were homemakers. Significant differences were found in responses of parents for an unwelcoming atmosphere in the school, bad experience in the past, language problems, schools located far, busy with work and attitude of parents regarding parent involvement. $65.6 \%$ of fathers and $40.5 \%$ mothers face problems and barriers and are very strongly dissatisfied. Only $5 \%$ of fathers and mothers are strongly satisfied with their involvement in school activities.
\end{abstract}

\section{Introduction}

Parents play an important role in the life of their child. They are considered to be the first teachers in the child's life. Communication between the parents and early childhood setting is vital. Parents are eager to know what their child has been doing during the time they are apart i.e. when they are in school. Therefore there should be proper communication between the parents and school.
Parent involvement means when parent/family, school and community come together for the betterment of the child. It also means some degree of participation by parent's at all major stages of an early education program. According to Brito \& Waller [2] parent involvement is a term that can include many different activities. It can range from an impersonal visit to the school to frequent parentteacher consultations. Parent involvement basically refers to the amount of participation a parent has when it comes to schooling and day to day activities of their child. According to Vandergrift \& Greece [19] there are two key elements that work together to make up the concept of parental involvement. One of these is a level of commitment to parent support. The other element is a level of parental activities and participation. This combination of level commitment and active participation makes a parent involvement.

Decades of research has shown that one of the most accurate predictors of child's achievement in school is not the family income or parental educational level, but the extent to which parents become actively involved in them [10].

\section{Importance of parent Involvement}

Parent involvement plays an important role in the development of a child. Studies have shown that high levels of parent involvement are associated with high and positive levels of academic achievements [9] and social-emotional competence [17] throughout childhood and adolescence. But whenever people talk of parental involvement the focus is more on mother rather than mother and father.

Research shows that greater parental involvement in children's learning positively affects the child's school performance including higher academic achievement [15], [18] and greater social and emotional development [4], [7].

Studies indicate that students with engaged families i.e. having good level of parent involvement, regardless of socioeconomic status or demographic culture background, were more likely to earn higher 
grades and test scores and enroll in higher level program, be promoted, pass their class and earn credits, attend school regularly, have better social skills, show improved behavior and adapt well to school, graduate and go on to post secondary education [13].

A review of the research on parent involvement reveals that parent involvement positively affects students' achievement [5], self esteem [12], behavior [8]; [16], graduation [11], emotional well-being [6] and life goals [11]. Most studies show that the value of education is impressed upon students when they see their parents and other family members involved in the school program [14]. Therefore the present study aims to find out the barriers to parental involvement in early childhood education classrooms in the Mumbai slums as perceived by parents.

\section{Aim}

To investigate barriers to parental involvement in early childhood education classrooms in Mumbai slums as perceived by parents.

\section{Methodology}

A sample of 150 parents (75 mothers and 75 fathers) was selected for the study from 10 preschools in Mumbai slums. Purposive sampling technique was used. A self constructed rating scale was prepared for mothers and fathers in order to collect data which consisted of 2 sessions: General Information and Parent Involvement Rating Scale which had 10 items under one broad category namely parent perceived problems and barriers for parent involvement.

Reliability of the tool for fathers by Correlation Coefficient Method: r=0.0992, r2: 0.984 and for mother by Correlation Coefficient Method: $r=0.0990$, r2: 0.980. Inter Class Correlation Coefficient Method Father $r=0.990$ Mother $r=0.989$.

10 preschools in the slums of Mumbai city were approached and permission was taken from each preschool. Date and time was fixed according to the convenience of the parents and researcher. Those who were willing to participate in the study were given the research tool which was translated into Hindi and Marathi (local languages) and appropriate instruction and purpose of the study was explained to them. Analysis was done using SPSS software. The data obtained was analyzed in terms of percentage and Chi-square.

\section{Results and Discussion}

\section{1. Demographic Information}

\section{a. Age of Respondents}

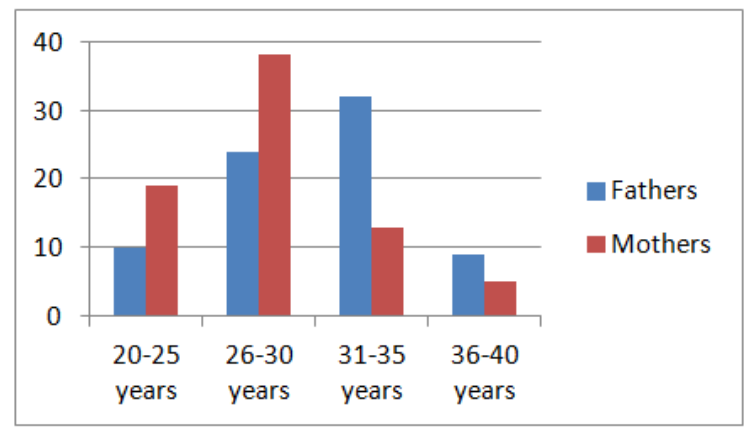

Figure 1. Age of respondents

The demographic information of parents who participated in the study is shown in the above table. Majority (32\%) of fathers were in the age group of 31-35 years where as majority $(38.6 \%)$ of mothers were in the age group of 26-30 years.

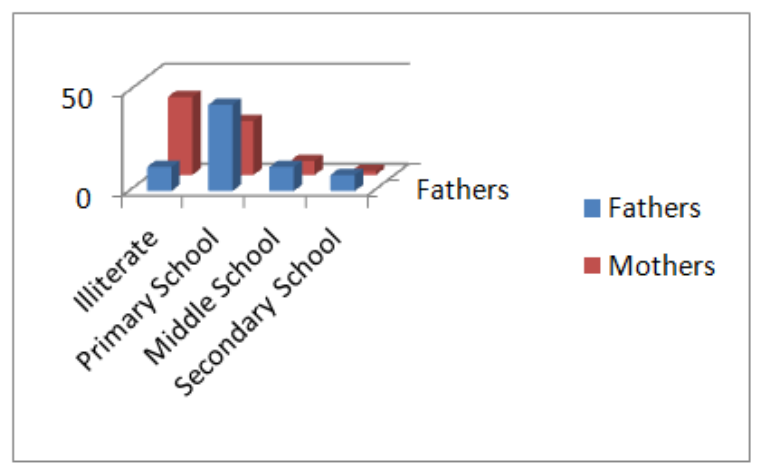

Figure 2. Educational qualification of parents

\section{b. Educational Qualification of Parents}

The above data speak sufficiently about the educational backwardness of men and women in the Mumbai slums. It is seen that 41 fathers were primary school pass and only 6 parents had passed secondary school. Majority of the mothers were illiterates (38) and only 2 mothers had passed secondary school.

Considering the fact that there is high illiteracy among the slum dwellers, especially among the women, children face more difficulties in pursuing their education. Even if the children manage to attend the school, they remain deprived, as they do not 
receive academic help from their parents. Poor school functioning and no help from the parents impact children greatly on their academic achievement. However, many a times the parents cannot fully help them and the children have to depend upon the tutors.

\section{c. Occupational Profile}

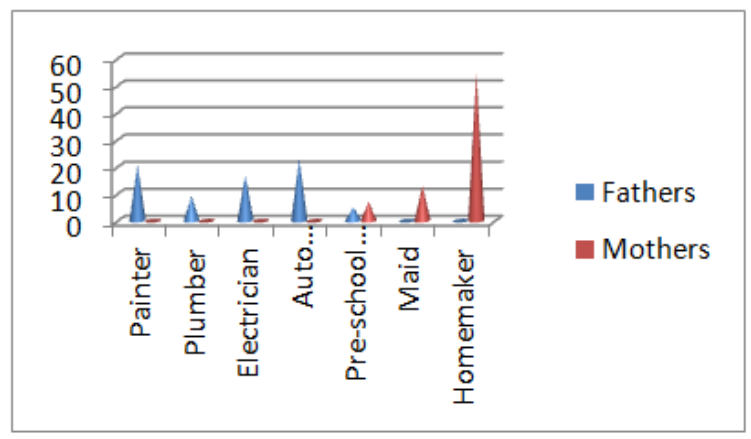

Figure 3. Occupational profile

Majority of the fathers (23) were Auto rickshaw driver and 21 were painters where as 55 mothers were homemakers and 13 mothers were working as maids. This could be because of low education levels in mothers. There were no mothers working as plumbers, painters, electricians and auto rickshaw drivers.

\subsection{Parent perceived barriers}

Table 1 shows the information about the parents perceived problems and barriers for involvement. Significant difference can be seen in the following mentioned problems/barriers:

a. Responses of parents for no welcoming atmosphere at the school revealed that mothers $(77.3 \%)$ and $44.9 \%$ fathers were very strongly dissatisfied and $0 \%$ mothers and $01.3 \%$ fathers were very Strongly Satisfied. Significant differences were found $\mathrm{p}=0.0007$.

b. While analyzing bad experience in the past shows that $76.0 \%$ mothers and $52.0 \%$ fathers were very strongly dissatisfied $0 \%$ mothers and $02.7 \%$ fathers were very Strongly Satisfied. Significant differences were found $\mathrm{p}=0.0002$.
Table 1. Parent perceived barriers

\begin{tabular}{|c|c|c|c|c|}
\hline Barriers & Respondents & $\begin{array}{l}\text { Chi Square } \\
\text { Value }\end{array}$ & df & Sig \\
\hline \multirow{2}{*}{$\begin{array}{l}\text { No knowledge of } \\
\text { school system }\end{array}$} & Mother & 1.54 & 2 & 0.46 \\
\hline & Father & & & \\
\hline \multirow{2}{*}{$\begin{array}{l}\text { No welcoming } \\
\text { atmosphere at school }\end{array}$} & Mother & 14.28 & 2 & $0.0007^{*}$ \\
\hline & Father & & & \\
\hline \multirow{2}{*}{$\begin{array}{l}\text { Bad experience in the } \\
\text { past }\end{array}$} & Mother & 17.5 & 2 & $0.0002 *$ \\
\hline & Father & & & \\
\hline \multirow{2}{*}{$\begin{array}{l}\text { Resistance to involve } \\
\text { in formal groups and } \\
\text { committees in the } \\
\text { school }\end{array}$} & Mother & 4.79 & 2 & 0.09 \\
\hline & Father & & & \\
\hline \multirow[t]{2}{*}{ Language problem } & Mother & 12.07 & 2 & $0.002^{*}$ \\
\hline & Father & & & \\
\hline \multirow{2}{*}{$\begin{array}{l}\text { Younger child at } \\
\text { home to be looked } \\
\text { after }\end{array}$} & Mother & 5.77 & 2 & 0.05 \\
\hline & Father & & & \\
\hline \multirow{2}{*}{$\begin{array}{l}\text { School located far } \\
\text { from home }\end{array}$} & Mother & 38.38 & 2 & $0.00^{*}$ \\
\hline & Father & & & \\
\hline \multirow[t]{2}{*}{ Busy with office work } & Mother & 40.84 & 2 & $0.00^{*}$ \\
\hline & Father & & & \\
\hline \multirow{2}{*}{$\begin{array}{l}\text { Conduction of } \\
\text { meetings on week } \\
\text { days }\end{array}$} & Mother & 5.01 & 2 & 0.0816 \\
\hline & Father & & & \\
\hline \multirow{2}{*}{$\begin{array}{l}\text { Attitude of parents } \\
\text { regarding } \\
\text { involvement }\end{array}$} & Mother & 38.38 & 2 & $0.00 *$ \\
\hline & Father & & & \\
\hline
\end{tabular}

c. Data of language problems revels that $64.0 \%$ mothers and $50.7 \%$ fathers were very strongly dissatisfied $17.3 \%$ mothers and $09.3 \%$ fathers were very Strongly Satisfied. Significant differences were found $\mathrm{p}=0.0002$.

d. Significant differences $\mathrm{p}=0.000$ were also found in School located far from home $72.0 \%$ mothers and $36.0 \%$ fathers were very strongly dissatisfied and $02.7 \%$ mothers and $02.7 \%$ fathers were very Strongly Satisfied.

e. In the analysis problem/barrier of busy with office work, significant difference $\mathrm{p}=0.00$ was found. $80.0 \%$ mothers and $28.0 \%$ fathers were very strongly dissatisfied and $01.3 \%$ mothers and $0.53 \%$ fathers were very Strongly Satisfied. Significant differences were found $\mathrm{p}=0.00$. 
f. Attitude of parents regarding parent involvement data revealed that $46.7 \%$ mothers and $37.3 \%$ fathers were very strongly dissatisfied and $13.3 \%$ mothers and $0 \%$ fathers were very Strongly Satisfied. Significant differences were found $\mathrm{p}=0.0007$.

\subsection{Overall Response to barriers of Fathers and Mothers}

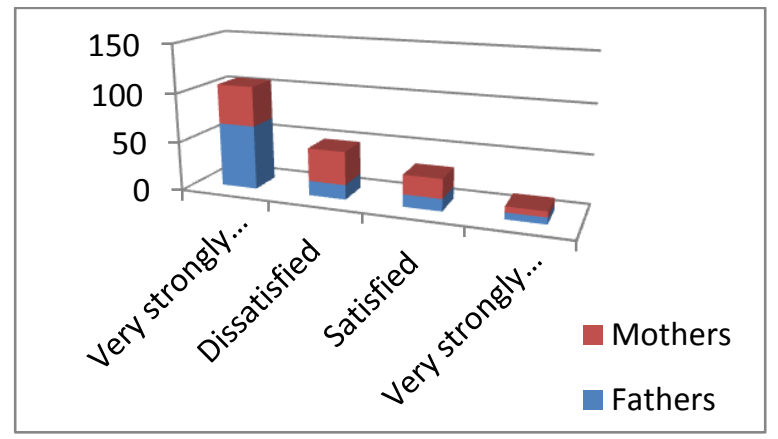

Figure 4. Overall response to barriers of fathers and mothers

Table 1 depicts the response of fathers and mothers while perceiving problems and barriers. It can be concluded that overall $65.6 \%$ of fathers and $40.5 \%$ mothers face problems and barriers and are very strongly dissatisfied. Only 5\% of fathers and mothers are strongly satisfied with their involvement in school activities. One of the reasons for fathers to perceive problems and barriers could be due to their business and long working hours and failure to manage time. Mothers are more involved because they work as professionals and can manage their time better to involve in their child's education. This is supported by a study by Bonney et al. [3] who reveals that longer working hours were the barriers to greater participation in child-care and education.

\section{Conclusion}

Parents play an important role in the child's life. For a child both the relationship ensures survival and helps to shape his/her future. Involving parents in school activities is a long standing tradition based on both theory and research. $32 \%$ of fathers were in the age group of 31-35 years where as $38.6 \%$ of mothers were in the age group of 26-30 years. Significant differences were found in responses of parents for an unwelcoming atmosphere in the school $(\mathrm{p}=0.0007)$, bad experience in the past $(\mathrm{p}=0.0002)$, language problems $(\mathrm{p}=0.0002)$, school located far from home $(\mathrm{p}=0.000)$, busy with office work $(\mathrm{p}=0.00)$ and attitude of parents regarding parent involvement $(\mathrm{p}=0.0007)$.

In overall response to barriers of fathers and mothers it was found that $65.6 \%$ of fathers and $40.5 \%$ mothers face problems and barriers and are very strongly dissatisfied. Only $5 \%$ of fathers and mothers are strongly satisfied with their involvement in school activities.

Parent involvement supports to bridge the gap that exists between home and school therefore the schools should try to create areas of parental involvement which in turn would benefit the school also. Research shows that parental involvement in their children's learning positively affects the child's performance at school [8]. Therefore it is recommended that parents may be honored by school management and teachers for their contribution towards school, and parents should also try to develop a relationship with teachers who are working with their children, guide or train parents to work with their children at home. Train school staff on how to make families welcome at school and also train parents to better assist at home through parenting skill instruction, teaching non-reading parents to read, and helping families obtain suitable reading materials for home.

\section{References}

[1] Berger, E. H. (1991). Parents as partners in education: The school and home working together. New York: Macmillan.

[2] Brito, J. \& Waller, H. (1994). Partnership at a price? In R. Merttens, D. Mayers, A Brown \& J. Vass, (Eds) Ruling the Margins: Problematizing Parental Involvement. London: Institute of Education, University of London, 157166.

[3] Bonney, J. F., Kelley, M. L., \& Levant, R. F. (1999). A model of fathers' behavioral involvement in child care in dual-earner families. Journal of Family Psychology, 13, 401-415.

[4] Bredekamp, S., \& Copple, C. (1997). Developmentally appropriate practice in early childhood programs. Washington, DC: NAEYC.

[5] Epstein, J., Sanders, M., Simon, B., Salinas, K., Jansorn, N., \& Van Voorhis, F. (2002). School, family, and community partnerships: Your handbook for action (2nd ed.). Thousand Oaks, CA: Corwin Press.

[6] Epstein, J. L. (2005). Attainable goals? The spirit and letter of the No Child Left Behind Act on parental involvement. Sociology of Education, 78, 179-182. 
[7] Fantuzzo, J. \& McWayne. (2002). The relationship between peer play interactions in the family context and dimensions of school readiness for low income preschool children. Journal of Educational Psychology, 94(1), 79-87.

[8] Fan X. \& Chen M (2001) Parental Involvement and Students' Academic Achievement: A Meta-Analysis, Educational Psychological Review Volume 13, Number 1, March 2001 , pp. 1-22(22)

[9] Flouri, E. \& Buchanan, A. (2004). Early father's and mother's involvement and child's later educational outcomes. British Journal of Educational Psychology, vol. 74, 141-153.

[10] Henderson, A. T., \& Berla, N. (Eds.). (1994). A new generation of evidence: The family is critical to student achievement. Washington, DC: Center for Law and Education.

[11] Lommerin, C. S. (1999). What middle level principals do to encourage and nurture parent involvement: A qualitative study. Unpublished doctoral dissertation, Temple University, Philadelphia, PA.

[12] Mapp, K. (1997). Making family-school connections work. The Harvard Education Letter, 13, 1-3.

[13] Mattson, S (2010). Family Engagement in Education. Offices of Research and Education Accountability, (61)5, 401-788.

[14] Myers, J., \& Monson, L. (1992). Involving families. Columbus, OH: National Middle School Association.

[15] McNeal, R. B. (1999). Parental involvement as social capital: Differential effectiveness on science achievement, truancy, and dropping out. Social Forces, 78(1), 117-144.

[16] National Middle School Association. (2003). This We Believe: Successful Schools for Young Adolescents. Westerville, $\mathrm{OH}$; Author.

[17] Overbeek et al. (2007). Stability in Bullying and Victimization and its Association with Social Adjustment in Childhood and Adolescent. Journal of Abnormal Child Psychology, Vol. 35 (2), 217-228.

[18] Scribner, J.D. (2003) Parent Involvement: Influencing Factors and Implications. The Journal of Educational Research, 9491), 42-54.

[19] Vandergrift, J., \& Greene, A. (1992). Rethinking parent involvement. Educational Leadership, 50(1), 57-59. 